\title{
The comparison and analysis on optimal status of Best Management Practice (BMP) mixed technique to reduce urban flood discharge in Tehran District 4
}

\author{
Professor Dr. Sorush Niknamian \\ Board Member of Weston A Price Foundation, Washington Dc, USA \\ E-mail: so.niknamian@gmail.com
}

\begin{abstract}
Nowadays, damages caused by flood are deemed as one of the important concerns for urban management. This study aims to analyze effects of coefficient of runoff to urban flood using one of the Best Management Practice (BMP) hybrid techniques with respect to change in use of urban lands and development in urban administration to reduce urban flood discharge. District 4 is one of 22 municipal districts in Tehran city as the east water basin with over $61.4 \mathrm{~km}^{2}$. In this investigation, runoff coefficient was calculated by means of Geographic Information System (GIS) to determine rise of this coefficient in hydrological computations using of Storm Water Management Model (SWMM) techniques to adjust urban flood. Similarly, the level of effect was evaluated for four parameters of gradient (slope), roughness coefficient, Curve Number (CN), and impermeability on change of use. With respect to results of sensitivity analysis of peak discharge, this system has the maximum sensitivity in terms of parameter of impermeability percent due to change of use so that following to $10 \%$ increase in impermeability, the output discharge of hydrograph runoff was increased $15 \%$ and due to $10 \%$ reduction in impermeability level, output discharge of hydrograph runoff was decreased $19 \%$. Curve Number (CN) has highest sensitivity after parameter of impermeability percent and following to $10 \%$ increase in CN parameter, the output discharge of hydrograph runoff was increased $15 \%$ while by $10 \%$ reduction in roughness coefficient, output discharge of hydrograph runoff was reduced $8 \%$. After implementation of model with the given mixed scenario through comparing of discharge in 10year return period, it was characterized that the maximum reduction rates occurred in output No 2 (26.8\%) and output No 7 (54.3\%).
\end{abstract}

Keywords: Geographic Information System (GIS), Urban flood, Discharge network, Runoff coefficient

\section{1- Introduction}

The damages exerted by flood are one of the important subjects and problems which have been seriously discussed and analyzed today and various solutions are suggested for prevention from the related consequences and damages with respect to geographical 
situations at any region. In fact, as construction and development of cities are done in wider extent at the same time impermeability levels are increased further and also it is added to ground runoffs. Flood is one of the most destructive and hazardous natural disasters throughout the world [1] and they are still assumed as concern for many points of the world [2]. For example, the report No 4 of Intergovernmental Panel of Climatic Change (IPCCAR4) showed that flood was probably as one of the main reasons for regional concern in countries with warmer climate [3].

The floods included $40 \%$ of total natural disasters of the world occurred during 1985 to 2009 and they have led to extensive destruction and a lot of economic loss and fatalities in the world [4]. At present, flood is one of the greatest threats for social safety and sustainable development and it is approximated annually the floods to aft detrimentally about 20-300 millions of people [5]. With approximately $700 \mathrm{~km}^{2}$ of surface area and population of 12 millions of people, Tehran is deemed as one of metropolises in the world. Tehran has special features and characteristics. Discharge system and guiding and collection of ground waters of Tehran include several complexities which are mainly due to heterogeneous development of this city and regardless of comprehensive urban design criteria.

Rising of water impermeability levels caused by urban development has change regional hydrological regime where this has intensified urban floods. Ground water drainage and collection system of Tehran widely follows land gradient and this issue is more tangible at northern zones in this city. With respect to pending of northern mountains of Tehran to this city and mountainous condition in these areas, drainage system not only collects and transfers inter-city runoffs, but also moves runoffs in city outside regions. The water basin field of mountainous areas pending to Tehran city is about $678 \mathrm{~km}^{2}$ and this causes intensifying of flood risk at this district and due to high value of urban lands in Tehran, limit of river may not be observed in many intervals and this can exert irrecoverable hazards and damages to regional inhabitants if flood takes place.

This study aims to analyze effects of change in use and urban development on runoff coefficient and urban flood by Storm Water Management Model SWMM at Tehran District No 4 and in addition it is discussed about other objectives such as recognition and review of effective factors on reduction of urban flood, analysis on the given results, and survey and comparison of the given results from the aforesaid paths.

\section{2- Research literature}

\section{2-1- Domestic studies:}

It was shown through analysis of various methods to control flood using descriptiveanalytical method that among non-structural and structural techniques, flood insurance management and floodgate methods were respectively the most applied techniques for controlling of flood and runoffs in cities [6]. In similar studies, the ground water runoff 
discharge grid was simulated using of MIKE SWMM model in combination with GIS in Mashhad water and power fields [7]. Revision of urban runoff collection system was studied by simulation of MIKE-SWMM in the eastern Eqbal zone at Mashhad and it showed that the airport downstream bridge was the most critical point in the simulated system at eastern Eqbal flood grid and it caused repulsion and blocking of the flow as a result the runoff stream returned to the upper side and caused flood [8].

Some studies were conducted concerning application of fluvial permeation models for simulation of water permeation in controlling basins of urban flood and it was identified that among urban flood controlling techniques the rain water permeation technique into land was one of the foremost techniques to prevent from flood damages. The results indicated that three models of Dupuit- Forchheimer (assumption), Ernest - Miles had lesser sensitivity to their parameters than in Morel-Sytox model [9]. Likewise, they concluded in their study that by analysis on sub-basins of isometric level locating at the middle part of aquifer, maximum effect occurred at the peak discharge of output flood from the main basin with over $64.46 \mathrm{~km}^{2}$ [10]. Using of descriptive-analytical methodology following to interpretation of executive strategies, Low Impact Development (LID) is employed for design and development of urban spaces. Data collection was done based on librarian and documentary studies in this paper. The research findings suggest that one could achieve more sustainable development in urban spaces through some strategies such as improvement of infrastructures, utilization of impermeable surfaces, using runoffs for irrigation of vegetation, reduced cleaning and ranking levels and the like [11]. The researchers analyzed quantitative and qualitative management in some part of Tehran District 22 and they reviewed the best administrative solution using EPA SWMM model. Their findings showed that green roof technique was the best administrative solution selected for the given zone [12].

\section{2-2- Foreign studies:}

Several studies were carried out regarding analysis of LID on urban flood management compared to urban discharge systems. They examined LID effects on excavated and humid lands, permeable asphalt, and green roof. The results of this survey showed that all of the studies items affected reducing of runoff volume but the peak intensity was different for them. This study was intended to determine quantitative and qualitative management of urban flood using EPA SWMM model to plan for reduction of flood solid materials and decrease in urban flood peak [13].

They conducted studies about flood risk modeling for Central Business District (CBD) by means of Analytical Hierarchy Process (AHP) system, and Geographic Information System (GIS) and the working results were analyzed and suitable administrative and executive solutions were proposed to reduce flood risk and the related hazard [14]. 
He tried to compute and determine effect of variance of urban development on rise of flood risk and floods return period in a metropolis in Nigeria and finally concluded that urban development drives might create seasonal floods and increase flood risk within the studied zone and highest and foremost variations of flood risk effects were the rate of controlling of weak floods and at the same time some of factors for this loss included lack of appropriate and proper and inadequate drainage system and absence of regular construction design and unprincipled buildings and poor management [3].

\section{3- Theoretical bases}

Since 1960s, ground water drainage network of Tehran was analyzed in three studies through comprehensive plan project and only some part of this project was executed while population of Tehran city has been increased ten times and wideness of this city has also noticeably grown. Most of the problems relating to their quantity and quality originate from city development and rise of city-dweller population.

However nowadays it is tried to employ most of administrative in a water basin to realize the designated objectives for reducing of runoff flow discharge. A new concept, called Best Management Practices (abbreviated as BMPs), has been proposed for quantitative and qualitative control of urban floods during recent years. While in some countries including USA and Australia the structural and non-structural techniques (called BMPs) have been widely developed in control of urban floods, so far no efforts has been made for optimal presentation of by considering a group of them for quality and quantity control of urban floods along with applied models of hydraulic and hydrologic simulations (SWMM \& SWAT).

Suitable technical studies have been carried out by a new technique to control urban flood using of simulation model at different levels and effective results were derived [16].

Through dividing of city and upstream water sub-basins into smaller units and capable for study of urban development in this survey and analysis of urban design subjects and variations caused by land uses in the city and coverage of passages and roofs of houses by impermeable materials; on the one hand, this trend leads to increase doubly runoff due to atmospheric precipitations and at the same time it has increased volume of urban runoff and discharge peak and occurrence within shorter time and also the probability of given water storm has been also added at the downstream districts in that city. In order to establish proper urban administration for control and optimal use of ground waters due to rainfall, we should accurately recognize complex process of runoff production and formation in urban environments thereby we can adapt effective urban management to increase quantitatively and qualitatively social and welfare practices to improve urban life.

Likewise, in another study, which was carried out regarding recognition of the best efficient and favorable administrative techniques on the studied zone (Sao Paulo in Brazil), all of 
effective factors were analyzed in urban construction for control of runoff and peak discharge of urban flood under existing conditions and the best method was identified and introduced [17].

\section{4- Materials and methods}

\section{4-1- Introducing of studied zone}

Concerning history and introducing of District no 4, it can be mentioned that Tehran District 4 is one of the areas at northeast of this city. This landscape includes wide view from Alborz Range piedmonts and extensive green areas inside the limit of the district e.g. valleys adjacent to Latian Dam and verdant valleys locating on Fasham, Ushan, Meygoon, and sporting-recreational district of Darbandsar, Shemshak, and Abali at the east side of Tehran as a megalopolis. This area is limited from the north to line- 1800 and limit of District 1 , and from the west to Langari Street with District 1, and in Pasdaran Ave adjacent to Region-3, and from the south it is limited to border of Resalat Ave with District 7 and 8, and within Damavand Ave with District 13, and from the east to the limit of District 4. District No 4 has been identified as one of the most populated, widest, capable to receive immigrants, and more constructed districts in Tehran city.

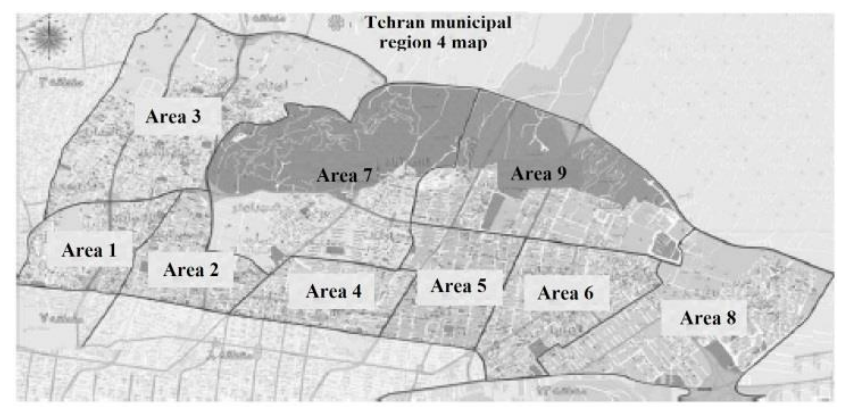

Fig 1: District No 4 of Tehran city

Review of studies indicates that since 1960s, drainage network of ground waters in Tehran city was reviewed by three major studies through comprehensive development plan but only some part of this project has been implemented while population of Tehran has been increased 10 times and wideness of city has remarkably grown at that time. In other words, many urban problems are currently related to quantity and quality of urban development and rise of city-dweller population.

The current existing main network for collection and drainage of ground waters in Tehran city has been mainly constructed according to the studies and projects that have been prepared during 40 years ago and they have been revised for several times by these three major studies. These studies are as follows:

1- Tehran- Irandco flood control studies (1966-1969);

2- Tehran- Gibb et al. (1973-1977) ground waters comprehensive plan; 
3- Comprehensive plan for guiding of Tehran ground waters (amendment and modifications) - Environment Civil Company (1999-1993)

The main drainage system of Tehran city comprises of 4 major parts including:

1- West and Kan River floodgate basin; 2- Eastern floodgate basin; 3- Central basin; and 4Western basin of Kan River

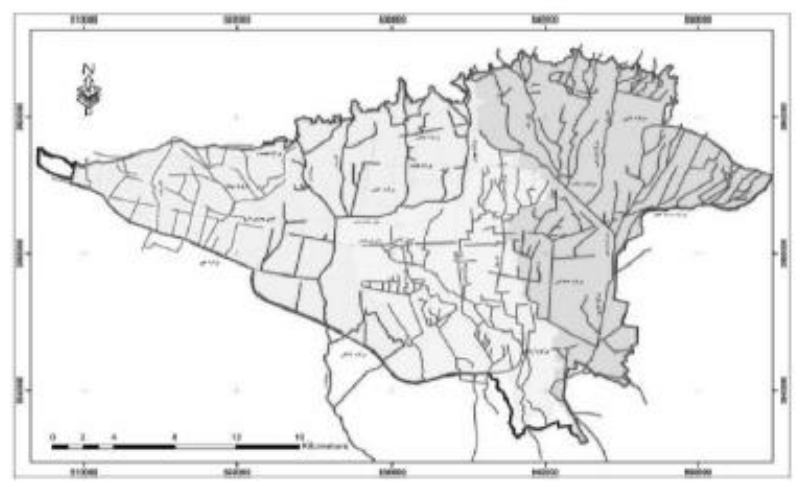

Fig 2: Drainage system and water basins of Tehran city- Comprehensive plan

This project was implemented after validation by rational technique of model for return periods (2, 5, and 10 years). District No 4 of Tehran city has been also selected in the current research. For example, both Tehranpars and Sorkheh Hesar drainage basins are also located in this district for which the ground waters collection grid of this basin has been analyzed at the current study using SWMM software.

\section{4-2- Methodology}

The needed information was collected for execution of various processes of this project with respect to selected field including the related maps and reports to the former studies of the project comprising of comprehensive, detailed and or guiding projects of city, geographic situation, city area, form and way of urban development and the existing physical status and future development and review of possible variations, statistics and information of meteorological stations in this zone including rainfall, historic showers, intensity-time relations, and frequency of showers and other information such as reports, maps, and information about type of lands, soil properties, data collection about ground waters and measurement of discharge at 10 output points.

The roughness coefficient designated for ground waters collection network in the given zone is presented in form of covered quadrangle with 0.0145 (water industry and waterwastewater Co standard, 2011).

Likewise, the needed rainfall statistics for this study were prepared from data extracted by Doushan Tapeh hygrometric station locating in longitude $\left(51,30^{\prime}\right)$ and latitude $\left(42,35^{\prime}\right)$ from Iranian Meteorological Organization. The rainfall data include 6-hour raining with return 
periods (2, 5, and 10 years). Fig 15-3 shows intensity-time curve to the rainfall return period in Doushan Tapeh station for various return periods (2, 5, 10, 20, 50, and 100 years).

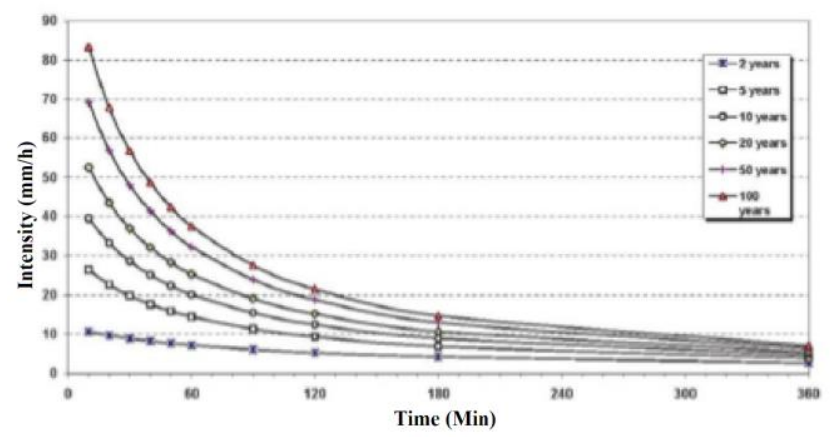

Fig 3: Intensity- time- rainfall return period curve in Doushan Tapeh station (2015)

In those cases when use of lands is led to various computational points it is necessary to determine average runoff coefficient for the given field. The mean runoff coefficient of the basin led to computational point should be computed by weight averaging.

Using of GIS techniques in this study, maps of city lands use were integrated into hydrological zonings with runoff coefficient standard table and average runoff coefficient was derived through the city. The zoning map of runoff coefficient in city was merged into plan of activity zone of municipalities in 22 districts of Tehran.

The estimate discharge in the model was calculated and determined using rational method according to the following table.

The rational formula has been presented in metric system as follows:

$Q=\frac{1}{360} C i A$

In above-said formula, $Q$ denotes maximum or peak of given runoff $\left(\mathrm{m}^{3} / \mathrm{s}\right) ; C$ is runoff coefficient or surface flow coefficient; $i$ as intensity of uniform mean rainfall on surface of field for return period of design and duration amounts to field focus time $(\mathrm{m} / \mathrm{h})$; and $A$ as surface area of basin (per hectare).

Table 2: The calculated discharge in model

\begin{tabular}{|c|c|c|c|c|c|c|c|c|c|c|}
\hline Outputs & Output & Output & Output & Output & Output & Output & Output & Output & Output & Output \\
& 1 & 2 & 3 & 4 & 5 & 6 & 7 & 8 & 9 & 10 \\
\hline $\begin{array}{c}\text { Section } \\
\text { form }\end{array}$ & Box & Box & Canal & Oval & Box & Canal & Canal & Canal & Canal & Canal \\
\hline $\begin{array}{c}\text { 2-year } \\
\text { discharge }\end{array}$ & 2.02 & $1.2 * 8$ & $5.1 * 1.7$ & $\mathrm{~h}=1.9$ & $2 * 2.8$ & $3 * 4$ & $2 * 25$ & $3.3 * 5.9$ & $3.6 * 5$ & $2 * 5$ \\
\hline
\end{tabular}

Table 3: Curve number in development of cities [18]

\begin{tabular}{|c|c|c|c|c|}
\hline Soil hydrologic groups & A & B & C & D \\
\hline $\begin{array}{c}\text { Curve number for urban lands } \\
\text { (except from vegetation) }\end{array}$ & 77 & 86 & 91 & 94 \\
\hline
\end{tabular}


Similarly, curve number method (SCS) method has been utilized for modeling of permeation in SWMM model and dynamic wave technique employed for hydraulic routing. Likewise, the selected Low Impact Development (LID) samples were extracted from SWMM model [19].

The quantity of CN was designated 80 for total network without BMP [20].

\section{5- Research findings}

\section{5-1- Runoff coefficient}

All surface areas were calculated in determination of runoff coefficient by means of GIS software:

In 2015, total area of Tehran District No 4 includes $49.61 \mathrm{~km}^{2}$ with superstructure area (property substructure) of $22.954 \mathrm{~km}^{2}$, area of paths (highways, streets, alleys etc.) $12.718 \mathrm{~km}^{2}$, and site area (lands, yard, and properties etc.) $18.337 \mathrm{~km}^{2}$ with surface of green space with $7.481 \mathrm{~km}^{2}$. If we also compute above-said items as percent of total amount, it was observed in 2015 it included over $46.65 \%$ of total surface area of Tehran as superstructure and substructure of properties, $32.81 \%$ as communication network and paths, and $20.54 \%$ as site of these areas. Of course, in order to prepare status of Tehran District No 4 in 2015, one block in Area 5 of District No 4 was initially studied at smaller scale (given Area 5 includes two newly constructed and worn urban textures which are adapted to status of Tehran District No 4) and afterward it was studied by means of maps (1:2000) of total District No 4. Likewise, with respect to the coefficient of selected runoffs shown in Fig (3), the average runoff coefficient of this district is derived about 0.47 . The average runoff coefficient of this basin in Tehran city districts was led to preparation of Table (2) that proposes quantity of runoff coefficient in reach of municipal areas.

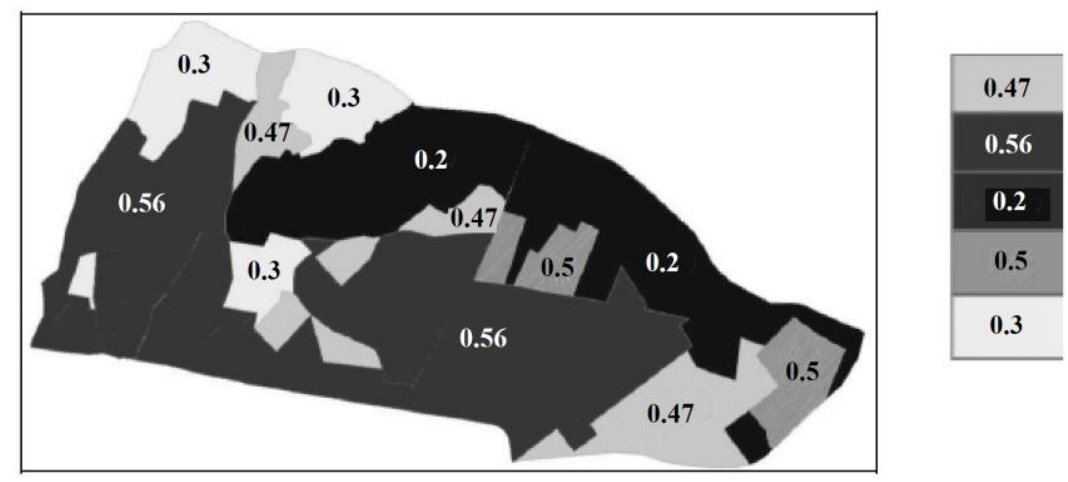

Fig 4: Coefficient of selected runoffs in modeling

The rate of effect was evaluated for four parameters of gradient (slope), roughness coefficient, $\mathrm{CN}$, and impermeability in the results of this model. 


\section{5-2-Simultaneous combination of two scenarios- optimal mode}

The combined method for increase at permeation level and permeable pavement and infiltration trench

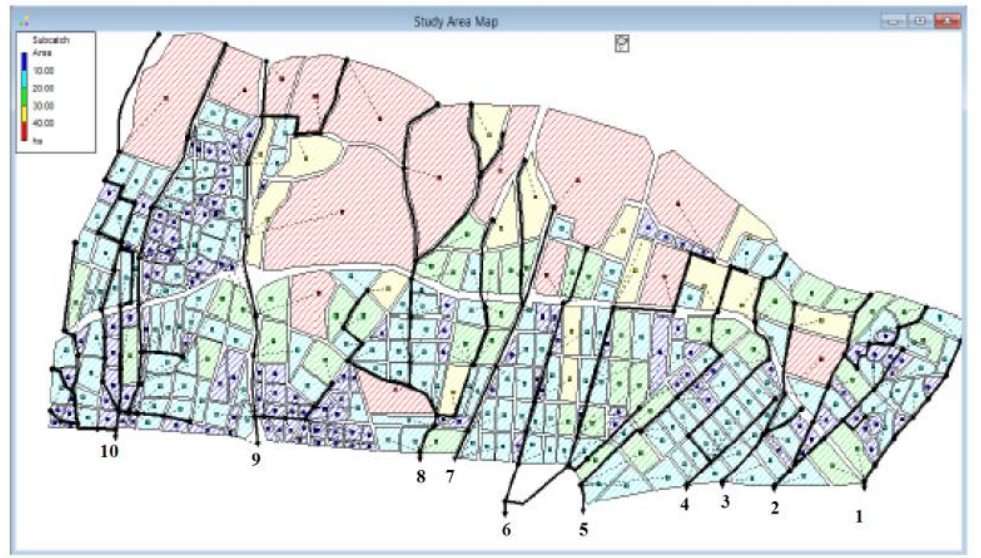

Fig 3-4- The outputs defined in the model

Regardless of partial executive constraints in this scenario it is modeled by preference for adjustment of urban flood discharge to the same given 10 outputs:

Table 25- Results of modeling of third scenario for 2-year return period

\begin{tabular}{|c|c|c|c|c|}
\hline Output & $\begin{array}{c}\text { Section form in } \\
\text { output (height } \times \\
\text { width) }\end{array}$ & $\begin{array}{c}\text { Model 2-year } \\
\text { discharge } \\
\text { (CMS) }\end{array}$ & $\begin{array}{c}\text { Runoff } \\
\text { height }(\mathbf{M})\end{array}$ & $\begin{array}{c}\text { Speed in } \\
\text { output } \\
(\mathbf{m} / \mathbf{s})\end{array}$ \\
\hline 1 & Box 2.8*2 & 1.23 & 0.15 & 3 \\
\hline 2 & Box 2*1.8 & 2.98 & 0.31 & 5.6 \\
\hline 3 & Canal 5.1*1.7 & 1.79 & 0.1 & 3.9 \\
\hline 4 & Oval height 1.9 & 3 & 0.52 & 3.7 \\
\hline 5 & Box 2.8*2 & 2.46 & 0.3 & 2.85 \\
\hline 6 & Canal 3*4 & 8.95 & 0.7 & 4.33 \\
\hline 7 & Canal 2*2.5 & 1.4 & 0.18 & 3.9 \\
\hline 8 & Canal 3.9*3.5 & 6.84 & 0.5 & 3.73 \\
\hline 9 & Canal 6*3.5 & 7.6 & 0.22 & 4.9 \\
\hline 10 & Canal 2*5 & 10.3 & 1.11 & 4.66 \\
\hline
\end{tabular}

Table 26- Results of modeling of third scenario for 5-year return period

\begin{tabular}{|c|c|c|c|c|}
\hline Output & $\begin{array}{c}\text { Section form in } \\
\text { output (height } \times \\
\text { width) }\end{array}$ & $\begin{array}{c}\text { Model 5-year } \\
\text { discharge } \\
(\mathbf{C M S})\end{array}$ & $\begin{array}{c}\text { Runoff } \\
\text { height }(\mathbf{M})\end{array}$ & $\begin{array}{c}\text { Speed in } \\
\text { output } \\
(\mathbf{m} / \mathbf{s})\end{array}$ \\
\hline 1 & Box 2.8*2 & 3.29 & 0.27 & 4.34 \\
\hline 2 & Box 2*1.8 & 7.5 & 0.5 & 7.6 \\
\hline 3 & Canal 5.1*1.7 & 4.62 & 0.16 & 5.7 \\
\hline 4 & Oval height 1.9 & 8.1 & 0.95 & 5 \\
\hline 5 & Box 2.8*2 & 6.5 & 0.6 & 4 \\
\hline 6 & Canal 3*4 & 15.92 & 1 & 5.14 \\
\hline 7 & Canal 2*2.5 & 3.91 & 0.35 & 5.5 \\
\hline 8 & Canal 3.9*3.5 & 18.3 & 0.9 & 5.2 \\
\hline 9 & Canal 6*3.5 & 20.2 & 0.46 & 7.3 \\
\hline
\end{tabular}




\begin{tabular}{|l|l|l|l|l|}
\hline 10 & Canal $2 * 5$ & 23.98 & 2.16 & 5.5 \\
\hline
\end{tabular}

Table 27- Results of modeling of third scenario for 10-year return period

\begin{tabular}{|c|c|c|c|c|}
\hline Output & $\begin{array}{c}\text { Section form in } \\
\text { output (height } \\
\text { width) }\end{array}$ & $\begin{array}{c}\text { Model 10-year } \\
\text { discharge } \\
(\mathbf{C M S})\end{array}$ & $\begin{array}{c}\text { Runoff } \\
\text { height }(\mathbf{M})\end{array}$ & $\begin{array}{c}\text { Speed in } \\
\text { output } \\
(\mathbf{m} / \mathbf{s})\end{array}$ \\
\hline 1 & Box 2.8*2 & 5.18 & 0.36 & 5.1 \\
\hline 2 & Box 2*1.8 & 11.82 & 0.7 & 8 \\
\hline 3 & Canal 5.1*1.7 & 7.2 & 0.2 & 6.7 \\
\hline 4 & Oval height 1.9 & 12.7 & 1.34 & 5.5 \\
\hline 5 & Box 2.8*2 & 10.2 & 0.8 & 4.6 \\
\hline 6 & Canal 3*4 & 21.22 & 1.3 & 5.6 \\
\hline 7 & Canal 2*2.5 & 6.33 & 0.5 & 6.5 \\
\hline 8 & Canal 3.9*3.5 & 28.7 & 1.24 & 5.9 \\
\hline 9 & Canal 6*3.5 & 31.31 & 0.61 & 8.5 \\
\hline 10 & Canal 2*5 & 35.61 & 3 & 5.9 \\
\hline
\end{tabular}

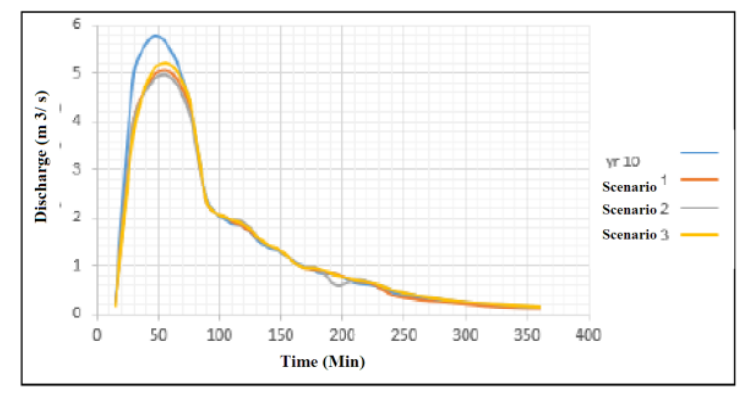

Output 1

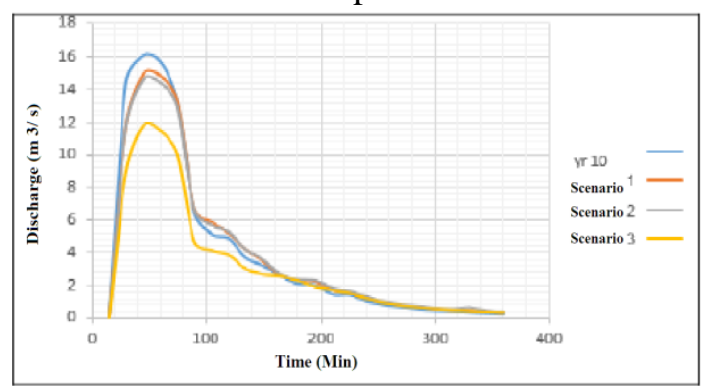

Output 2

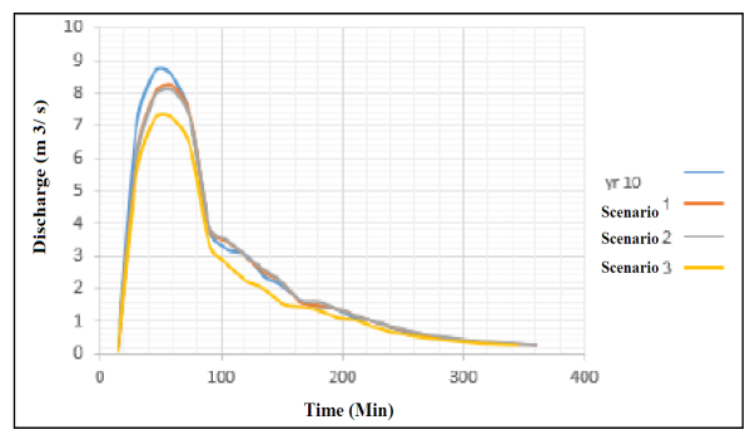

Output 3 


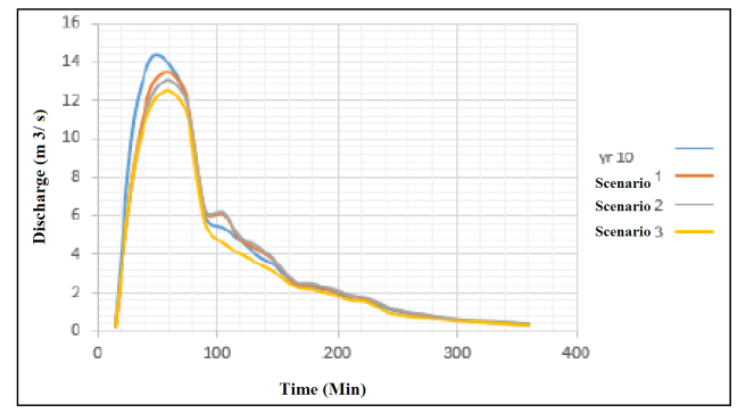

Output 4

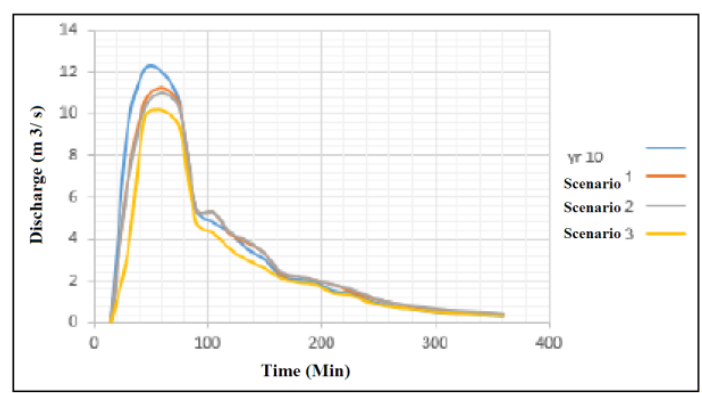

Output 5

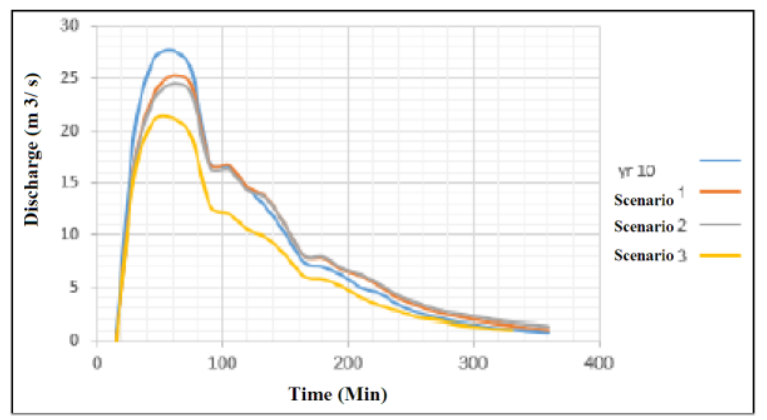

Output 6

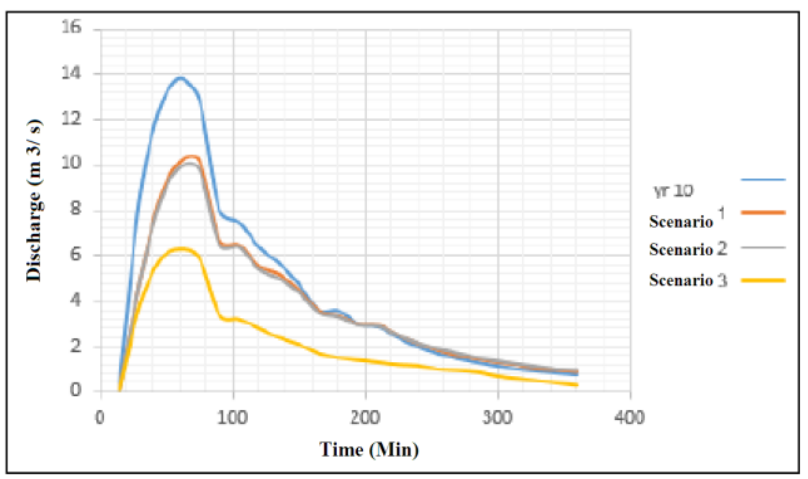

Output 7 


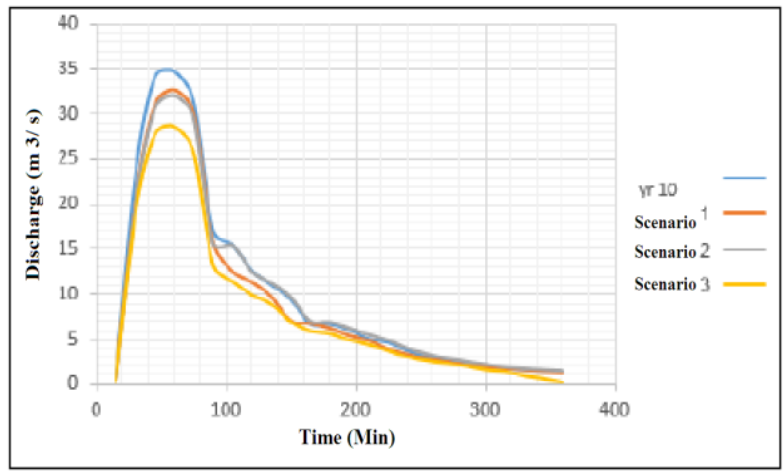

Output 8

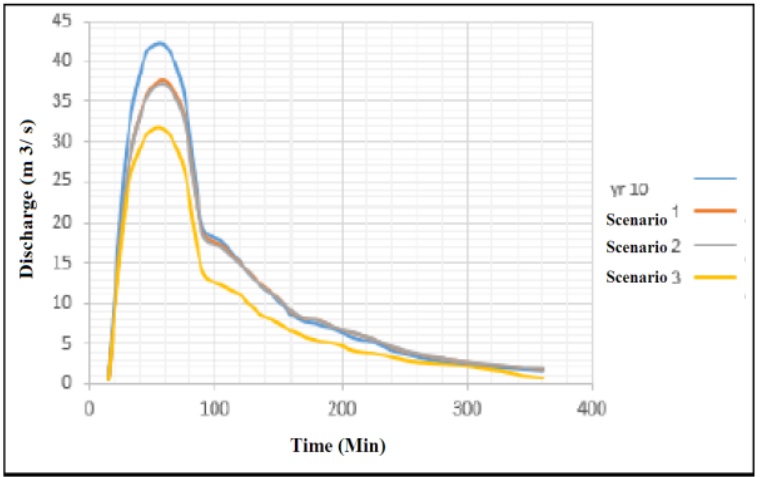

Output 9

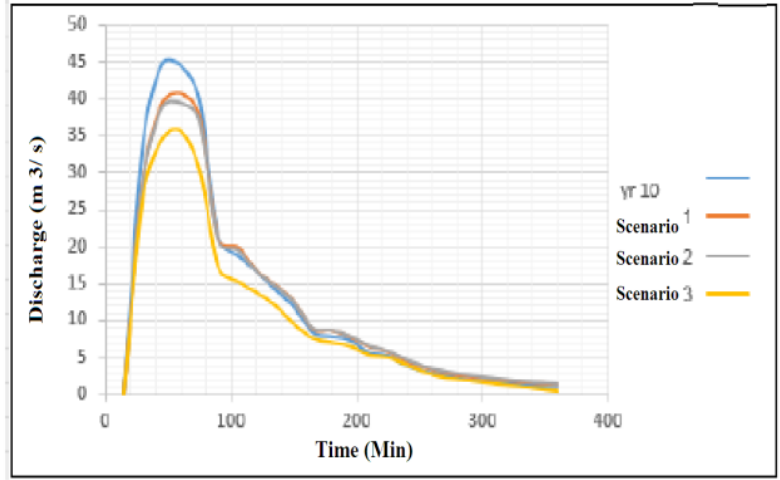

Output 10

Table 3-5: Results of discharge in outputs of the model

\begin{tabular}{|c|c|c|c|}
\hline Output & $\begin{array}{c}\text { 10-year discharge } \\
\left(\mathbf{m}^{3} / \mathbf{s}\right)\end{array}$ & $\begin{array}{c}\text { Discharge } \\
\text { scenario }\left(\mathbf{m}^{\mathbf{3}} / \mathbf{s}\right)\end{array}$ & $\begin{array}{c}\text { Reduction } \\
\text { percent }\end{array}$ \\
\hline 1 & 5.75 & 5.18 & 9.9 \\
\hline 2 & 16.14 & 11.82 & 26.8 \\
\hline 3 & 8.64 & 7.22 & 16.4 \\
\hline 4 & 14.18 & 12.5 & 11.5 \\
\hline 5 & 12.15 & 10.2 & 16 \\
\hline 6 & 27.73 & 21.2 & 23.5 \\
\hline 7 & 13.78 & 6.3 & 54.3 \\
\hline 8 & 34.76 & 28.7 & 17.4 \\
\hline 9 & 42 & 31.4 & 25.2 \\
\hline 10 & 44.73 & 35.6 & 20.4 \\
\hline
\end{tabular}




\section{6- Conclusion and suggestion 10}

\section{6-1- Conclusion}

With respect to results of sensitivity analysis, the gradient parameter in main canals and roughness coefficient of canal have no high effect on peak discharge of hydrograph output. The peak discharge in this district has the maximum sensitivity versus parameter of impermeability percent due to change in natural use to residential use so that by 10 percent increase of impermeability, rate of peak discharge for output runoff has been added $15 \%$ and following to $10 \%$ reduction in impermeability, peak discharge of output runoff has decreased $19 \%$. After parameter of impermeability percent, Curve number (CN) has the highest sensitivity and by $10 \%$ increase in $\mathrm{CN}$, rate of peak hydrographic discharge for output runoff has increased $15 \%$ and following to $10 \%$ reduction in roughness coefficient, rate of peak hydrographic discharge for output runoff has reduced $15 \%$. Therefore, it should be taken high care for simulation of urban runoff in section of $\mathrm{CN}$ and impermeability percent.

Sensitivity analysis showed that the ground runoff was directly related to impermeability parameter and it is inversely related to parameter of roughness coefficient.

With respect to results of validation, error is less than $10 \%$ and with respect to Journal No 584 (Manual for application of mathematical and physical models in engineering studies and river organization), the model is placed within very favorable limit.

In validation of Maximum Relative Error (MRE), the ratio of peak discharge in output-1 is $9.7 \%$ and minimum error $3.3 \%$ is seen in output -7 .

There is little difference among 5-year and 10-year peak discharges in flood hydrograph of the base model but there is more difference among 2-year and 5-year peak discharges.

The maximum height of runoff in 2-year, 5-year, and 10-year return periods is respectively $1.5 \mathrm{~m}, 3 \mathrm{~m}$, and $3.7 \mathrm{~m}$.

The maximum speed of runoff in 2-year, 5-year, and 10-year return periods is respectively $7.9,9.9$, and $10 \mathrm{~m} / \mathrm{s}$.

There is speed rate higher than $6 \mathrm{~m}^{3} / \mathrm{s}$ in $10 \%$ of network within 2-year return period and following to longer return period, more percent of network may reach to this speed. With respect to high gradient of network, this may be unexpected and network should be corrected.

In some outputs at this study, $73 \%$ of section is full for 10 -year return period and in some others almost $80 \%$ of this section is full. Compared to some of similar former conducted studies such as survey in Mashhad eastern Eqbal basin and Tehran District No 22, it was seen that precision of results and outputs were firstly confirmed and at the second the findings have suggested that the current status in ground waters collection grid might not be 
responsive to the rise of runoff coefficient and thus increase in flood peak discharge with respect to the given urban constructions and development and at the same time this issue can be managed by employing of administrative methods and with rising of impermeability (Tajbakhsh, 2012). Likewise, with respect to impossible developing for ground waters collection network, using of BMP and addressing to administrative issues is deemed as necessary in reducing of urban flood and the final results suggest lack of suitable efficiency in various parts of the existing ground waters collection grid in the studied zone. This subject has been realized in results of similar studies such as analysis of quantitative and qualitative management of urban flood by EPA SWMM model in Tehran District No 22 as well and the administrative strategies were suggested.

\section{6-2- Suggestions:}

1- The urban land use should be changed by a formulated plan in accordance with comprehensive and detailed project of Tehran and if adverse changes are exerted in use of properties and urban lands, runoff coefficient and thus flood peak discharge will be increased according to hydrograph of urban flood.

2- Tehran city has been developed without certain planning and with specific distribution in recent years and this has also led to disruption in ground waters collection system with respect to expansion of city so it is suggested to take more urgent measures through coordination with Tehran City Limit Administration to determine city limits and stop city development more quickly.

3- As it mentioned, the most important of current research was the simulation and assessment of performance of ground runoff drainage system in some part of Tehran (District No 4) therefore with respect to water shortage problem it is better to adapt administrative methods to control urban runoff and flood discharge. Similarly, it can be suggested that given urban development and impossible development of ground waters collection network to use BMP that seems to be necessary in reducing of urban flood.

4- It is suggested in this regard to utilize BMPs which are capable for feeding of underground water table. This natural process affects longer stability of subterranean water supplies because rate of extraction from underground water supplies should not exceed from the related feeding rate.

5- Given the geographic, hydrologic, and hydraulic conditions in the studied zone, it is suggested in this investigation to employ simultaneously techniques for increase of permeability levels and permeable pavement and infiltration trench.

Utilization of BMP administrative techniques, especially above-said methods, can be economically cost-effective and it may need to very lower costs for maintenance and depreciation. 


\section{7- References:}

1-Wilby RL, Keenan R. (2012). Adapting to flood risk under climate change. Progrom Physices Geography 36(3):348-378.

2-Jha, A,K, Bloch R, Lamond J. (2012). Cities and flooding: a guide to integrated urban flood risk management for the 21st century. The World Bank, Washington, DC.

3-Solomon S, Qin D, Manning M, Chen Z, Marquis M, Averyt KB, Tignor M, Miller HL (eds) .(2007). Climate change the physical science basis. Contribution to Working Group I to the fourth assessment report of Intergovernmental Panel on Climate Change. Cambridge University Press, Cambridge.

4-Ferreira S, Hamilton K, Vincent JR, Nature. (2011). socioeconomics and adaptation to natural hazards: new evidence from floods. Policy research working paper. The World Bank, Washington, DC.

5- Hirabayashi Y, Kanae S. (2009).First estimate of the future global population at risk of flooding. Hydrol Res Lett 3:6-9.

6-Uraei Zare and Erfan Drati,1396, "Exploring the Structural Management Methods of Urban Runoff in Crisis, Third Annual Conference of Urban Architecture", Urban and Urban Management Studies, Shiraz, Architectural and Urban Design Institute of Safiran Road Mehraz. in persian.

7-Fallah Tafti A and Partners,1385," Simulation of surface runoff drainage network using Gis model, Mike SWMM Case Study of Mashhad Water and Power Basin", First National Conference on Engineering of Channels.

8-Tajbakhsh,M,Khodashenas,S,2010,"Revision of Surface- Runoff Drainage System by Simulation and Application of Retention Basins (Case Study: East Eghbal Catchment, Mashhad)", journal of water and soil, 31 January 2010 in Persian.

The application models of influence rivers for simulation water "9- Khodashenas,S,1387, . Journal water and sewage.number 67.page66. in "influence in urban flood control basins

persian 10- Rogani,m,gafori,a Tabatabaei,M,1384,"The application method location effective levels on peak flood in anticipate results flood control ", 3th central research soil safeguarding and aquiferous country.in Persian.

Planning for Sustainable Development of Urban "11-Montazer Al-Hajja, Mahdi,1396, , Fourth International "Environments with Low Impact Development Approach (LID) Conference on Environmental Planning and Management, Tehran, University of Tehran Environmental Faculty.in persian. 12- Mozafari, J., and Kabardfard M,1396," Quantitative and qualitative management of urban flood management with the EPA SWMM model". Case study: District 22 of Tehran, Quarterly Journal of Engineering and Water Engineering, Number Twenty-seventh. in persian.

13- Hua, Zhuo, Fu Guangtao .(2013). "The effects of low impact development on urban flooding under different rainfall characteristics" Journal of Environmental Management. 
14- Generino P. Siddayao , Sony E. Valdez, Proceso L. Fernandez.(2015). Modeling Flood Risk for an Urban CBD Using AHP and GIS.IJIET . E Journal Publishing.

15- Saidu Idris, Lal Merving Dharmasiri.Department of Geography.(2016). Urban Development and the Increasing Trend of Flood Risk in Gombe Metropolis.Nigeria. International Journal of Science and Research.

16-Zhifeng Li, Lixin Wu, Wei Zhu, Miaole Hou, Yizhou Yang and Jianchun Zheng. (2014). A New Method for Urban Storm Flood Inundation Simulation with Fine CD-TIN Surface.water journal,5May 2014.

17-N.C.B. Moura, P.R.M. Pellegrin and J.R.S. Martin. (2014). Best management practices as an alter native for flood and urban storm water control in a changing climate. Journal of flood riskmanagement. September 2014.

18-Hawkins, R.H.; Jiang, R.; Woodward, D.E.; Hjelmfelt, A.T.; Van Mullem, J.A. (2013). "Runoff Curve Number Method: Examination of the Initial Abstraction Ratio". Proceedings of the Second Federal Interagency Hydrologic Modeling Conference, Las Vegas. Nevada. U.S. Geological Survey. doi:10.1111/j.1752-1688.2006.tb04481.x. Retrieved 24.

19- Rossman L.A.(2010).storm water management model.User's manual. Version 5.0 United states Environmental Protection Agency.

20- Alizadeh, A., 1395,"Principles of Applied Hydrology", Imam Reza University Press, Mashhad.in Persian. 